\title{
The Passion for Sexual Difference: On (Re)Reading Angela Carter's

\author{
The Passion of New Eve
}

Paola Bono

\section{La passion de la différence sexuelle ou la (re)lecture de The Passion of New Eve d'Angela Carter}

Cet essai trace des lectures et des (re)lectures de l'oeuvre d'Angela Carter, analysant la lecture comme une performance avec des signes pour en faire sens. La lectrice se situe en tant que partisan dans/par sa lecture qui est à la fois une lecture d'opposition au sens établi et une lecture de mise en position, à travers un engagement féministe. Dans cette optique, les textes de Carter sont dérangeants par leur mise en scène d'une sexualité d'excès voisinant, semble-t-il, la fétichisation pornographique. Cependant, relue dans l'optique de la mimésis, tel qu'Irigaray le conçoit, c'est-à-dire comme un jeu de répétition visant à exposer l'élément performatif de la répétition qui produit la femme, la fiction de Carter se voit comme cette répétition visant à demasquer les codes de la performance de la féminité, à rendre visible ce qui a été invisible. Ce travail de déstabilisation, tout comme le travail de la (re)lecture, est du "bricolage," un assemblage de textes divers qui, répétés dans une configuration nouvelle, change les habitudes de performance par où l'on représente le féminin tout autant que par où l'on lit un texte d'une écrivaine.

1. Double, sometimes duplicitous needs.

These experiences of difference which produce different consciousnesses, different cultural expression, different relation to the realm of symbols and to symbol users...

Essentialist? No. We are making a creation, not a discovery.

Rachael Blau DuPlessis (280-1)

For some time now, increasingly so and increasingly often, I have found myself engaged - actually, I have been and still am teaching myself to be engaged - in a partisan reading of the world. Reading as a metaphor: a mode of being and of positioning the self in the world, signifying the world to make sense of it. That is, giving it sense in 
order to be given it back, a sense in which to represent myself as a subject of knowledge and therefore of life.

For reading, as an active mode of apprehension and cognition - a taking hold of, dynamic relation of the consciousness acting and being acted upon - is, like cognition itself, an operation of both representation and interpretation. Neither passive reception nor arbitrary intervention, but structuring interaction which brings forth a recognizable knowledge, recognized by a subject historically and experientially situated.

The function of the observer, which has been ascribed such a central importance in contemporary thought, is the function of the reader. No text, and in the text no meaning, can exist, if the reader does not make sense of it. It has actually been argued that reading existed before writing, when "natural" signs were recognized and interpreted: a broken twig, the musk growing on the northern side of a tree, footmarks and clouds. One can read a book, a face, a landscape; there is no unity in these objects, no common denominator, except the intention to read.

The text of the world and the single texts which compose it; they are written and read within the strong but not immutable web of symbolic systems, systems of representation which also construct the world they represent. And the observer, the reader, is at the centre of the web: one can be the spider weaving it, or the fly mortally taken in its threads. A partisan reading is my way of re-weaving the web, actually trying to be both (that is to say, neither).

Partisan in two ways: on the one hand an "oppositive" reading, one which resists the already-given forms of symbolization (ordering) of experience, and in so doing disrupts the complicity with exclusion, fully appropriating it as a dynamic and therefore modifiable factor. Without complaints, going all the way, knowing and acknowledging the authority for and the authorship of the pars destruens of my process of recognition, positioning/relating of the self in/to its being. Partisan subjectivity in its resistance to any identification with symbolic forms which require a blinding of intelligence, the obliteration if not the oblivion of my experience, my cathexis in images founded on my negation.

On the other hand, a partisanship which might be called, borrowing a little-loved dictum of political language, "positive discrimination" in reading. Or, if you will, the reproposition, be it purely in terms 
of a working hypothesis, of that old, much maligned and perhaps rather too prematurely discarded motto of Italian feminism "donna è bello" - woman is beautiful, or even womanity is beauty. I do not like hasty or summary judgements of another woman's work; always I want to go, little by little, in search of a measure, its and my measure, a woman's measure. To criticize, eventually, to criticize ferociously if necessary, but not along the lines of an introjected gaze responding to parameters "objectively" deceptive; nor according to feminist assumptions which would become established as new articles of faith.

In both cases - oppositive reading, positively discriminatory reading - the suspension of judgement and the rethinking of the hypotheses are the steps my reading takes, as it makes and remakes itself against the background of questions posed to the text and to myself. Asking whether and how a text: presupposes me as a possible, respected interlocutor; inscribes me in its texture of signs instating a liveable and workable image of myself; assumes me positively as having, being a sexed identity. And if the answers do not please me, taking to task for it both the text and myself.

A process of re-vision, then, which I find particularly useful for certain texts produced by men which I instinctively like, yet experiencing a subtle, inexplicable feeling of unease. And for certain texts produced by women which I instinctively - but confusedly - dislike. Thus the instinctive response is not denied, rather it is posited as an initial yardstick in the process of discovery and knowledge. But it is also subjected to verification, put into doubt in order to make it fully responsive to my interest and therefore profitable. (Even instincts may be culturally constructed/inducted, cheating Trojan horses in the citadel of the self.)

Such re-vision does not concern itself solely with old texts, in that recrossing of the cultural tradition which has led feminists to analyze anew the patrimony of the past, uncovering its biases and discovering a hidden wealth of feminine voices. Indeed, I would say that it is especially valid for contemporary texts, often so deceptively marked by the changes feminism has wrought, or so deceptively innocent of their mark - at times even deceptively inimical.

Suspension of judgement, rethinking of the hypotheses, as I move, and in order to be able to move, with/in the unlimited network of interconnections which is the world, which is a text. In that reciprocal 
awakening of meaning which marks the true passion of reading, that which so often leads to re-reading: like getting to know someone beyond a first impression, and in doing so learning to know oneself. Through one's eyes, senses, mind, a relationship is established, as our body meets the body of the text; in the partial withdrawal from one's world that the choosing of a fictional universe entails - even in the case of scientific texts - the relationship grows. Or dies.

Taking time, listening to that unease or confusion which accompanies the instinctive response, both protects the relationship and puts it at risk. Retracing the moments of pleasure or repulsion, questioning the reasons for my reactions (projections?), cautiously trying out new steps as in exploring the text I draw upon its connections with other texts in order to introduce my own. It is a movement which proceeds by conjectures and wagers, whose rightful destination cannot at its outset be said. The intention is the journey and in the journey is its purpose; only in the arrival - both a process and a site, marked by the instability of its conclusiveness - is the sense of the exploration revealed. For every path is right if that is where I wish to go; for the text answers me according to my questions, but the questions I search are born of the answers of the text.

2. Patriarchal society is based on authoritarian-exploitative relationships, and its sexuality is sadomasochistic. The values of power, of the domination of man over the other, are reflected in sexuality $[\ldots]$ The transformation of sexuality into a sadomasochistic model of power and submission means that effectively what in the male world is defined as sexuality is none other than perversion.

Movimento Femminista Romano (Bono 1991, 68)

With regard to Angela Carter's texts, this potentially infinite game seemed to me all the more necessary, an interrogation of her writing which would allow me to hypothesize the underlying questions, to then re-vise their answers, a starting point for new questions ... Because (why was it that?), the stories of The Bloody Chamber fascinated me, but I had not liked The Passion of New Eve: nor had reading her other novels and stories resolved this ambiguity of response. Because I sensed there an intention which I could not get hold of, the making of a project projected onto our cultural memory and the structuring of our contemporary experience which I wanted both to under- 
stand and to elude. And because, under the pressure of this fascination and refusal, I had interviewed her for an Italian feminist journal.

The idea of the interview took form in the context of a collective reflection of the editorial board about the concept of "projectuality." That underlying process founded in the relation between subject and action which shapes and is given shape by projects, but which also exists apart and beyond their existence. In exploring the meaning and the modes of such a process for women, I turned to Carter's texts and turned away from them, baffled by my own contradictory feelings. Turned from them to their author.

For the spoken word has an appeal that disappointments cannot cloud. We are forever beset by the temptation of its authenticity, the desire for a singular comprehension, a unique discovery which presence would guarantee, almost evoked, as if by a form of magic, by this direct contact. Thus it often seems that the interest and the pleasure, the uncertainty and the irritation which might occur when facing the written page - and especially perhaps the curiosity which wants to go beyond it and the laziness which wants to escape its challenge - might find their explanation and their fulfilment in asking not the writing but the writer.

Yet betrayal poisons "the realm of living speech;" the colloquial quality of a face-to-face interview, its same spontaneity, hypothetical guarantees of a full and unmediated expression, actually constrain thought. The spoken word confines it in a mutilating immediacy, a paradoxical form of mediation, cutting the ground from under the search for meaning and expression. Perhaps one should just read what writers write, and not go and talk to them - if not, as it were, "laterally."

Someone who writes, regularly and steadily, for whom writing is both a discipline of life and an inescapable need, both craft and vocation (a "profession" in its original duplicity of meaning), will often invest in the written word the deepest tension of their lives. In their case, the intentionality which structures one's sense of self and of the world, the "projectuality" which is process of knowledge and sustained explication of this sense of self and of the world, should then be sought and retraced in their writings. There are no shortcuts; or rather, they lead elsewhere. The elsewhere has its own interest, and can deviously speak of that which it is not - thus the elsewhere of an interview asks for its lack to be filled. 


\section{Tessera}

And I have gone back to Carter's writing, to find a path through the universe of her words. I have been dragged into her visionary worlds, sites of outrageous fantasizing, stories which interweave the macabre and the improbable with the possible, to become a commentary on reality. Expansion and trespassing of uncertain borders, into territories and events which indeed could, or might in the future, exist, and which surely exist in a dimension of the mind.

Dreams and visions have a concrete reality of their own, and nobody would deny the materiality of the life of the imagination, the solid weight of symbolic processes in the daily life of both individuals and the institutions which seek to order and prescribe their behaviour. The allegorical dimension of Angela Carter's novels offers alternative mental geographies, in which to make out possible coordinates for critical movement in the "real" world. The incredible is almost possible in her worlds, which appear to have only just trespassed - a few steps, no more - into the unreal. Here lies their relevance and their fascination, hypnotic attraction and simultaneous repulsion, like that of a carnivorous flower.

Carter is a convinced materialist; for her, social history and material conditions of life largely determine the formation both of individual sensibility and of interpersonal relations. And yet she writes hallucinated stories, in which is set free a sort of feverish, almost insane, mirth of the imagination, producing at times an intolerable feeling of proliferation and plenitude. Of excess.

Did my refusal stem from such a nausea, not only of the emotions, but of the intellect as well; was it a refusal to follow her in her exploration of sexuality, primary form of relating and potential metaphor of every other form? For in Angela Carter's writings excess is often the mode of female sexuality. Excess of degradation for Zero's wives in the Passion, enslaved by a totally interiorized slavery, convinced they are kept alive by his sperm. Excess of affirmation and dominance for the Great Mother, who in that same novel exalts only the reproductive function of sexuality, and uses man as a mere means of fertilization.

Or think of the heroines of some of her stories, Lady Purple for example, the puppet who comes to life and kills her creator: utter condensation of cruelty and unlimited sadism, "mistress of the whip ... she graduated in the mysteries of the torture chamber ... a baroque apparatus of funnel, humiliation, syringe, thumbscrew, contempt and spiritual anguish ... a sacrament of suffering" (WGWW 260). 
In fact, Carter's cool, frank, pitiless and at times vulgar investigation of sexuality, ranging the continuum of sensations from sheer pleasure to sheer horror -indeed collapsing them into the duplicity of passion - created for me a feeling of uneasiness, as it evoked at times the shadow of pornography and of its reified, mutilated use of sexuality. But perhaps "pornographers are the enemies of women only because our contemporary ideology of pornography does not encompass the possibility of change, as if we were the slaves of history and not its makers" (SW 3). Perhaps a "moral pornographer" can indeed exist, one who would use pornography "as a critique of current relations between the sexes" SW 19).

Old discussions in the '70s come back to my mind. Were we naive? Perhaps. More sophisticated analyses have been put forward since then, complicating the links between power and sexuality, exploring the complex ways in which the values of power and domination may rebound to/from sexuality, circumscribe its discourse, produce its norm and its model. A model of perversion, which pornography is often accused of upholding and reinforcing. But, in so far as it exposes in its hyperbolic stagings of the norm the very perversity of the norm, might pornography not have a subversive role?

"Sexual relations between men and women always render explicit the nature of social relations in the society in which they take place, and, if described explicitly, will form a critique of those relations ... the pornographer has it in its power to become a terrorist of the imagination ... to reinstitute sexuality as a primary mode of being rather than a specialised area of vacation from being..." (SW 19, 21-22).

Could it be so, I wondered; and started reading again.

3. To play with mimesis is, for a woman, to try to recover the place of her exploitation by discourse, without allowing herself simply to be reduced to it. It means to resubmit herself ... to "ideas," in particular to ideas about herself that are elaborated in/by masculine logic, but so as to make "visible," by an effect of playful repetition, what was supposed to remain invisible...

$$
\text { Luce Irigaray (76) }
$$

I had not liked The Passion of Nerv Eve: I decided to re-read it, at first simply looking for a key to attune to its forms, giving it credit as far as its answers were concerned, because I might have misconstrued their questions. 
The novel is constructed around the topos of the journey, and narrates the three, or perhaps four, journeys of Evelyn/Eve, the young English scholar who travels to the new world, and there goes west across the continent in search of himself, also covering the incommensurate space which separates him from the experience of life in a woman's body, and then leaves once more-headed where, we do not know. The title already signals the allegorical mode of the novel, recalling on the one hand the passion of Christ and, implicitly, the resurrection, and on the other hand identifying Eve as the subject of passion and rebirth. Or, rather, the "new" Eve: thus the archetype is evoked only to be consigned to the semantic field of obsolescence and death.

The events of the plot are linked in a linear temporality, but as each "station" of the way is crowded with memories rooted in the allembracing macrotext of our culture, the apparently traditional narrative structure is transformed, through a process of dilation rather than of fragmentation. For this reason, trying to summarize the plot is not only difficult (or too easy), but actually uninteresting. Too much is lost remaining on the surface of the story, woven as it is of the marvellous, the extravagant, the grotesque.

Everything must be read, read as one would read allegory, continuous deferral and suggestion of one or more embedded meanings, dissonance between saying and sense. Allos: the other; agoréuein: to speak openly, to argue in the agora. Allegory is marked by a double intention, it says in order to simultaneously say other from what it says. The discourse perceivable on the surface can in itself be the itinerary of an already significant narration, but the other is there and asks to be revealed; only in the relation is the realization of the sense. Allegory forges its chain of metaphors, making abstract the singular and the concrete, and giving abstractions a visible body in the imagination, and thus achieves its aim. Illumination, not concealment. The silences, the cruelties, the pleasures and the fears of the adventures of the spirit have always been the privileged terrain of allegory.

It is not surprising therefore that a discourse on sexuality as a "primary mode of being rather than a specialized area of vacation from being" (SW 22) - which means not forgetting its aspect of historically determined power relationship-should choose allegory as its form of expression.

In The Passion, however, there is no consistent rule in the relations of levels of meaning, no unambiguous correspondence of the literal 
and the allegorical, allowing an all-coherent translation from one into the other. All dualism is rejected, and the tertium non datur does not apply here. This elision, this inherently unstable truth which can be made manifest in both terms of the opposition, no longer irreconcilable, seemed at one point to be the answer I had been looking for, as I looked at the "figures" of sexuality in The Passion.

The great Mother, "a sacred monster. She was personified and selffulfilling fertility" (NE 59).

Zero the poet, lover of guns and hater of humanity, who believed "women were fashioned of a different soul substance from men," who was "Masculinity incarnate" (NE 87, 104).

Tristessa himself - ancient enchanting ghost of Hollywood, the transvestite who "had made himself the shrine of his own desires, had made himself the only woman he could have loved" (NE 128-29).

Figures of sexuality and excess, all phrases of a mystifying discourse which defines and labels, a discourse of power imprisoned in the narrowness of a partial representation which aspires to universality. Both Mother and Zero dream of a world made totally in their own image, dreams of a deluded omnipotence which is indeed exalting its own limits. In order to escape the Procrustean bed of one pole of the opposition, Tristessa has accepted its shaping of the other: "If a woman is indeed beautiful only in so far as she incarnates most completely the secret aspirations of man, no wonder Tristessa had been able to become the most beautiful woman in the world, an unbegotten woman who made no concessions to humanity" (NE 129). Excess, in the forms of hyperbole and masquerade, uncovers the unwholesomeness of accepted configurations of sexuality.

The apparently monumental body of the Mother (NE 59), gigantic, immobile, whose face "had the stern, democratic beauty of a figure on a pediment in the provincial square of a people's republic," but which is in fact a "handsome, austere mask" (my italics), is disrupted by the double tier of nipples, the irruption of the animal, "breasted like a sow," in the human body.

The grotesque asserts itself in this image of "self-fulfilling fertility," which reminds one of Bakhtin's comment about the Kerch figurines of old pregnant women: "This is typical and very strongly expressed grotesque. It is ambivalent. It is pregnant death, a death that gives birth. There is nothing completed, nothing calm and stable in the bodies of these old hags. They combine senile, decaying, and 
deformed flesh with the flesh of new life, conceived but as yet unformed" (Bakhtin 25).

Similarity and contrast both play a role in bringing to memory that image, and more generally Bakhtin's conception of the grotesque body, when confronted with the image of the Mother. Static and dynamic at the same time, her "ponderous feet were heavy enough to serve as illustrations of gravity" while her wrinkled skin, rucked "like a Greek peasant's goatskin bottle" (connotations of movement, aging, animality) "looked as rich as though it might contain within itself the source of a marvellous, dark, revivifying river, as she herself were the only oasis in this desert and her crack the source of all the life-giving water in the world."

Totalitarian and self-contained, but also open, oozing and protruding, this grotesque body confirms and reverses Bakhtin's model of the body politic by collapsing the capitalist/socialist analogy in bringing to the fore what was in his theory left unacknowledged. The "fear and loathing associated with the biological processes of reproduction" (Russo 219) impregnate the Mother. She is a figure of that "rhetoric of abjection" retraced by Kristeva in her analysis of Céline's texts; powerful horror which according to Mary Russo slowly permeates into the critical text as well, coming to rest in the category of the maternal (Russo 220).

Kristeva writes: "When Céline locates the ultimate of abjection ... in the birth-giving scene, he makes amply clear which fantasy is involved: something horrible to see at the impossible doors of the invisible: the mother's body. The scene of scenes is here not the so-called primal scene but the one of giving birth, incest turned inside out, flayed identity. Giving birth: the height of bloodshed and life, scorching moment of hesitation (between inside and outside, ego and other, life and death), horror and beauty, sexuality and the blunt negation of the sexual ... At the doors of the feminine, at the doors of abjection ..." (Kristeva 155-56).

Language becomes charged with horror, and the images of life and death coincide; blood colours the scene, and the feminine is the ultimate secret, annihilation and conquest. Thus in the underworld of Beulah (the Pilgrim's land of peace and joy turned into a station of the passion), in a room of closed, red walls, Evelyn is terrified by the booming refrain growing louder and louder in his ears. 
“... other women's voices took up the refrain: NOW YOU ARE AT THE PLACE OF BIRTH, NOW YOU ARE AT THE PLACE OF BIRTH [ ... ] I realised the warm, red place in which I lay was a simulacrum of the womb.

[...] in this room lies the focus of darkness. She is the destination of all men, the inaccessible silence, the darkness that glides, at the last moment, always out of reach; the door called orgasm slams in his face, closes fast on the Nirvana of non-being which is gone as soon as it is glimpsed. She, this darkest one, this fleshy extinction, beyond time, beyond imagination, always just beyond, a little way beyond the fingertips of the spirit, the eternally elusive quietus who will free me from being, transform my I into the other and, in doing so, annihilate it." (NE 52, 58-59)

I was terrified as well, terrified by my double identification in Evelyn's feelings and in the She where his terror originates. The ambiguous power of the maternal, and within that ambiguity my (a woman's) ambivalent position: one who can be a daughter and a mother, a mother and, in the carnal union of pregnancy, a son. Mother's sexuality is the experience of pregnancy and giving birth, the very experience which has been in our culture both degraded and exalted, a source of power turned into a reason for enslavement.

Her grotesque body bears the marks of idealization and abjection; looking at her was looking at myself as I knew I could be - I had beenseen. Revealed by her excess, my disgust and my fear awakened me to what I already knew: the necessity of a redefinition of the maternal as a bodily experience and as a symbolic category. An enterprise which feminist thought is addressing in a variety of ways, often contradictory and even conflictual: but nevertheless one on which, I feel, much of our future is at stake.

Counterparts of Mother's fertility (mystery and danger of the feminine at the threshold of femaleness) are Zero's sterility and his masculinity pushed to the extreme: parody of and commentary upon the forms of masculinity. But when excess is brought into play, it will not only emphasize and expand, but also cancel and confuse. Mother has Zero's violence - a most "unfeminine" trait according to the model which she is in a larger-than-life manner representing, but nevertheless a trait inscribed in the birth-giving-function. Zero is deprived of 
that most masculine power, the power to fertilize; "castrated," so he thinks (irony piled upon irony), by a masquerade of femininity. Yet both he and Mother pursue to the end their totalizing, constraining dreams of domination, negative utopias of the fullness of the One, either eliminating or moulding the other as a condition of existence.

Leilah/Lilith, the other Eve of the legend, and Evelyn / Eve, the new Eve, show that they know, in their different ways, the wisdom of mercy and the importance of relating, a true relation only being possible when the partiality of the One is acknowledged in a world of the Two.

"The vengeance of the sex is love" (NE 191), the ambiguous narrating voice tells us at the end of the story. A woman who was a man, who has been offered and has rejected the return to her (his) male status: "Leilah dived into her ruck-sack and produced a long, metal box about the size of an old-fashioned glove box. [ ... ] It was a miniature portable refrigerator. Inside, on a bed of dry ice, lay the set of genitals which had once belonged to Evelyn. "You can have them back, if you still want them." I burst out laughing and shook my head. She closed the box and sent it skimming over the waves." (NE 187)

Laughing. Like Bakhtin's old hags, or like the Medusa? An impregnated woman in whom another being is growing. Twice double. Who is speaking? The creature to be born will have "two fathers and two mothers," born of the union of Eve/lyn and Tristessa, both of them bride and bridegroom, two people who have both, though in different degrees, experienced and suffered the Other. Not by chance, two men who have had to question the being and the otherness of their bodily selves at the crossroads of nature and culture: sexuality. The "normal" laws of sexuality suspended in order to rethink the norm. The ambiguity is multiplied in the mysterious though always recurring duplicity of procreation.

Who is speaking? The same voice had begun: "The last night I spent in London, I took some girl or other to the movies and, through her mediation, I paid you a little tribute of spermatozoa, Tristessa" (NE 5). Who spoke, who is speaking in this discourse which structures itself through repetition in symbolically marked stages, yet outlines the itinerary of a process, a transformation which touches everything?

4. The continuous effort to adhere to the (always male produced) models of maleness and femaleness, the continuous withdrawal 
from them because of an unrestrainable perception of their lack of authenticity, have both been read as permanent elements in the history of our gender. Between the effort and the withdrawal there lies a space which must be interpreted because it is the space of our lives; which can be interpreted because our political history makes us aware of the sexed nature of this oscillation, and of the perversion of a mechanism which condemns us to be alien either to our sex or to the world.

DWF editorial board (Bono 1991, 187)

The allegorical journey of the Passion raises questions about being and becoming, the formation of the self, identity and representation. It stages the unresolved tension between one's own sense of self and its expression/reception in relation to others; an age-old problem, a "universal" one. But because it centers on sexuality and its forms, the Passion brings to the fore the sexed nature of the problem, as well as its links with issues of power. In doing so, it draws upon a plurality of texts, a kind of melting pot from which it brings forth memories of the Bible, of Greek mythology, of ancient religions, of Hollywood films. Bricolage is the obvious word which comes to mind, and indeed Carter herself uses it to define her way of writing, opposing it to myth much in the same way that Hal Foster does.

Myth - he writes - is a one way appropriation, and an act of power; bricolage is a process of textual play, of loss and gain: whereas myth abstracts and pretends to the natural, bricolage cuts up, makes concrete, delights in the artificial. (Foster 64)

"Writing - says Carter - is for me a process, a long work-in-progress; much of my writing has been an exploration of narrative genres in search of a form which would be viable as a vehicle for ideas. Emphasizing artificiality, choosing forms which explicitly assume it, which are indeed based on the foregrounding of their artificiality, has seemed to me a possible solution. Besides, I have an academic training as a medievalist, and the allegorical form of narration came to me so to say naturally, it was familiar... I have also indulged in a sort of intellectual bricolage - great fun; revisting and reutilizing our cultural heritage, as though it were a big junk shop, a gigantic scrapyard" (Bono 1986, 100). 
And in The Sadeian Woman, she affirmed: " ... consolatory nonsense seems to me a fair definition of myth ... Myth deals in false universals, to dull the pain of particular circumstances" (SW 5). Not a scrap of consolation is to be found in the great Mother, even before she ends up in a cave with a nervous breakdown. In the destabilization of the ideals of femininity lies a possible resolution of the pain of womanity not dulled, but fully acknowledged.

As it is only too obvious, such a destabilization includes that of the ideals of masculinity, and in the Passion both are achieved by a double movement of vertiginous accretion on the one hand - piling up events which also are memories of events, representations which reflect and multiply memories of representation - on the other hand sharply focusing on enlarged portions of this crowded picture, to uncover every detail until the precision of the description makes them look not real but artificial.

Bricolage: but reading can be bricolage as well, "a process of textual play, of loss and gain;" linking together scraps of one's encyclopedia, grafting them upon the text to (artificially?) produce questions and answers. One does it all the time, but perhaps in a re-reading such as the one I have been trying to describe the process comes to the fore, emphasized as it were by the determination to come to terms with one's instinctive response. The effort to reposition myself in the Passion meant attuning myself to its artificiality and its excess, and in order to do so I had to doubt my first reading, to look at it again through the filter of other texts. Cutting and pasting, listening to the echoes of other voices. It meant accepting the challenge of its figures of sexuality, deformed projections of the norm, figments of the male imaginary transformed by their inscription in a female text. The text of my re-reading, with its partisan engagement to find (to weave) my traces into its texture.

Looking for them in the convolutions of Carter's discourse; joining her in the exploration of the scrapyard of culture. Out of the junk she chooses, mixing high and low, Freud and blatantly commercial films, whose ingredients are already second-hand, used and modified by use. Reference to Hollywood is almost inevitable when speaking of illusions and of the production of illusions (myths?) as goods. Tristessa is one of the images of femininity constructed over time to serve male desire. Femininity as a consumer good, just as innocence, virility or patriotism, the Hall of the Immortals in Tristessa's glass 
palace, is a collection of invented personalities and of people shattered by these inventions.

The construction of an identity which serves an Other's desire is a difficult and painful process. Living in Zero's house, under his brutal dominion with his other seven wives, Eve/lyn - already physically a woman - must learn to behave according to the rules of her role. The rules are here pushed to the extreme, but none the less "normal" for that. Experiencing the loss of self which accompanies this apprenticeship, Eve/lyn intuitively comes to understand those mechanisms of adhesion and reserve which allow the survival of the self despite the role, while becoming aware of his past as the oppressor in her present as the oppressed.

"I was tense and preoccupied; although I was a woman, I was now also passing for a woman, but then many women born spend their whole lives in just such imitations.... And more than my body, some other equally essential part of my being was ravaged by him for, when he mounted me ... I felt myself to be, not myself but he; and the experience of this crucial lack of self, which also brought with it a shock of introspection, forced me to know myself as a former violator at the moment of my own violation." (NE 101-102)

Re-reading it, the passion of new Eve has become part of my passion, of my search for the meaning of sexual difference, and the answers which I had thought I had found have been transformed into questions to ask myself beyond the text. There has been no static and normative recognition of a solution to the endless labour of positioning myself as a sexed being. There has been an inscription of my presence as an interlocutor within the text, though at times having to negotiate this presence along lines and in ways that at first I would rather not have recognized.

Rejections, like pleasures, are symptoms; refusals ask to be brought into the open when they would seek concealment, and to be investigated when they reveal themselves. Re-reading, I have been forced to examine in a different light my attitudes towards pornography and maternity, sexuality and representation, identity and subjectivity. I do not know that I can now say that I "like" the Passion; perhaps some of the mixture of fascination and repulsion still lingers, perhaps my journey is not over. 


\section{Works Cited}

Bakhtin, Mikhail. Rabelais and His World, Bloomington: Indiana University Press, 1984.

Bono, Paola. "Intervista con Angela Carter," DWF, 2, 1986.

Carter, Angela. The Passion of Newv Eve, London: Virago Press Ltd., 1982, (first published by Victor Gollancz, 1977). References will be identified as $N E$ and included in the text.

Carter, Angela. The Sadeian Woman. An Exercise in Cultural History, London: Virago Press Ltd., 1979. References will be identified as SW and included in the text.

Carter, Angela. "The Loves of Lady Purple," in A. Carter ed., Wayzuard Girls and Wicked Women, London: Virago, 1986, (first published in A. Carter, Firezvorks, London: Harper \& Row, 1974). References will be identified as WGWW and included in the text.

DWF editorial board, "Belonging/ Pertaining" (1986), in Paola Bono and Sandra Kemp eds., Italian Feminist Thought. A Reader, Oxford: Blackwell, 1991.

DuPlessis, Rachel Blau. "For the Etruscans," in Elaine Showalter ed. The New Feminist Criticism. Essays on women, literature and theory, London: Virago, 1986.

Foster, Hal. "The 'Primitive' Unconscious of Modern Art," October, 34, 1985.

Irigaray, Luce. This Sex Which Is Not One, Ithaca, N.Y.: Cornell University Press, 1985.

Kristeva, Julia. Pozvers of Horror: An Essay on Abjection, New York: Columbia University Press, 1982.

Movimento Femminista Romano, "Male Sexuality - Perversion" (1976), in Paola Bono and Sandra Kemp eds., Italian Feminist Thought. A Reader, Oxford: Blackwell, 1991.

Russo, Mary. "Female Grotesques: Carnival and Theory," in Teresa de Lauretis ed. Feminist Studies/Critical Studies, London: Macmillan, 1988, (first published by Indiana University Press, 1986). 